\title{
The Use of English and the National Language on the Radio in ASEAN Countries
}

\author{
Amara Prasithrathsint (อมรา ประสิทธิธัฐสินธุ์) \\ Department of Linguistics, Faculty of Arts, \\ Chulalongkorn University, Bangkok, Thailand \\ amaraprasithrathsint@gmail.com \\ Kusuma Thongniam (กุสุมา ทองเนียม) \\ Independent researcher, Bangkok, Thailand \\ kusuma.thn@gmail.com \\ Pimpat Chumkaew (พิมพ์ภัทร ชุมแก้ว) \\ M.A. student, Department of Thai, Faculty of Arts, \\ Chulalongkorn University, Bangkok, Thailand \\ pimpat.chu@gmail.com
}

\begin{abstract}
The purpose of the present study is to examine language choice on the radio in ASEAN countries. The focus is on English and national languages, the two most important languages in those countries. A review of related past studies did not provide an answer to the question that we were interested in; i.e., which language is chosen for radio broadcasts in ASEAN countries between the national language, which is the language most people understand and signifies national identity, and English, which is the lingua franca of the region and an international language? Data was taken from a sample of programs broadcast by radio stations in the ten ASEAN countries. The results show that Singapore ranks the highest in using English in broadcasting (50\% of all the programs), while Laos, Cambodia, Myanmar and Vietnam rank the lowest in using English $(0 \%)$ but highest in using their national languages (100\%). Code-switching between the countries' national languages and English is found in five countries listed from highest to lowest as: the Philippines, Singapore, Brunei, Indonesia and Thailand. Codeswitching is absent in Malaysia, Myanmar, Cambodia, Laos and Vietnam. We conclude that despite the importance of English in the ASEAN community, most ASEAN countries prefer to use their national languages in radio broadcasting.
\end{abstract}

(C) AMARA PRASITHRATHSINT ET AL., 2019 | DOI:10.1163/26659077-02203001

This is an open access article distributed under the terms of the prevailing CC-BY-NC License at the time of publication. 


\section{Keywords}

radio language - English - ASEAN - national language

บทคัดย่อ

การใช้ภาษาอังกฤษและภาษาประจำชาติในสื่อวิทยุประเทศกลุ่มอาเซียน

วัตถุประสงค์ของบทความนี้ คือศึกษาการเลือกใช้ภาษาในวิทยุของประเทศกลุ่มอาเซียน โดยเน้น ภาษาอังกฤษและภาษาประจำชาติ ซึ่งทั้งสองภาษานี้เป็นภาษาสำคัญของประเทศดังกล่าว จาก การสำรวจงานวิจัยในอดีต ไม่พบผลงานใดที่ตอบคำถามของผู้วิจัย กล่าวคือ ภาษาใดถูกเลือกใช้ ในการกระจายเสียงทางวิทยุในประเทศกลุ่มอาเซียน ระหว่างภาษาประจำชาติ ซึ่งเป็นภาษาที่คน ส่วนใหญ่ในประเทศเข้าใจและเป็นภาษาที่แสดงอัตลักษณ์ของชาติ กับภาษาอังกฤษ ซึ่งเป็นภาษา กลางของภูมิภาคและภาษานานาชาติ ข้อมูลที่ใช้ในการวิเคราะห์ได้มาจากสุ่มตัวอย่างรายการที่ ออกอากาศโดยสถานีวิทยุในประเทศกลุ่มอาเซียน 10 ประเทศ ผลการวิจัยพบว่าประเทศสิงคโปร์ ใช้ภาษาอังกฤษในวิทยุมากที่สุด ( $50 \%$ ของรายการทั้งหมดในข้อมูล) ในทางตรงข้าม ประเทศลาว กัมพูชา เมียนมา และเวียดนามไม่ใช้ภาษาอังกฤษในวิทยุ $(0 \%)$ แต่ใช้ภาษาประจำชาติ $100 \%$ นอก จากนั้น ยังพบว่ามีการสลับภาษาระหว่างภาษาประจำชาติกับภาษาอังกฤษด้วย ซึ่งประเทศที่พบว่ามี การสลับภาษาเรียงจากมากที่สุดไปหาน้อยที่สุด ได้แก่ ฟิลิปปึนส์ สิงคโปร์ บรูไน อินโดนีเซีย และ ไทย ที่ไม่พบการสลับภาษาในวิทยุเลยได้แก่ มาเลเซีย เมียนมา กัมพูชา ลาว และเวียดนาม งานวิจัย นี้สรุปได้ว่าถึงแม้ภาษาอังกฤษมีความสำคัญมากต่อสมาคมอาเซียน แต่ประเทศส่วนใหญ่ในกลุ่มนี้ ยังเลือกใช้ภาษาประจำชาติของตนมากกว่าในการกระจายเสียงทางวิทยุ

1

Introduction

This article deals with radio and language choice in ASEAN countries. The reason why we chose to focus on the radio rather than other types of mass media is that radio is a very common and type of mass media. Receiving messages from the radio is more convenient than from other types of media because the audience can perform other activities while listening to the radio. Moreover, a radio set is so cheap that anyone can afford it. Lastly, in this digital age, radio broadcasts are readily and ordinarily accessible via the internet.

The purpose of this study is to examine language choice between English and the national languages ${ }^{1}$ on the radio in the ten ASEAN countries. Apart

1 A national language is defined here as a language spoken by the majority of the country's population. It is connected to the people and the territory of the country. It also serves as a symbol of the nation, in the same way as the national anthem and the national flag do. The national languages of the ten ASEAN countries; i.e., Brunei, Cambodia, Indonesia, Laos, Malaysia, Myanmar, the Philippines, Singapore, Thailand, and Vietnam, are Malay, 
from being an international language, English has been established as the lingua franca of the ASEAN community and it is being used in more and more domains in this region. In other words, English is taking over certain roles that used to be played by the national language of each ASEAN country. We want to observe between English and the national language, which is used more on the radio, the most common type of mass media.

We hypothesize that despite the impact of globalization, which leads to the need of using English in mass media, ASEAN countries still use their national languages more frequently than English on the radio.

Data used for analysis in this study was taken from radio broadcast programs via the internet from the ten ASEAN countries. The procedures are explained in the data collection part.

\subsection{Language Studies of Radio}

As radio is an important channel through which a message is transmitted in the form of speech, language choice is an important factor to consider in radio messaging. Indeed, a large number of past studies deal with the relation between radio and language in various aspects. The first aspect is about what language style is used in radio or whether radio language is formal or informal. ${ }^{2}$ According to Fishman (1991: 88-109), radio language is formal because most radio stations are operated by the government, but at the same time, it is also informal because it is spoken. Fishman seems to suggest here that it is not easy to determine whether radio language is formal or informal due to its two contrasting features: serious topics (governmental affairs), which are formal vs. talk, which is informal. Actually, Fishman wants to convey the idea of language shift; i.e., if the content on the radio becomes more governmental, then indigenous language, ${ }^{3}$ which is used in informal talk, would be replaced by

Cambodian, Indonesian (Bahasa Indonesia), Lao. Malay, Myanmar, Filipino, Malay, Thai, and Vietnamese, respectively.

It should be noted that the definition of "national language" may not totally apply to the national language of Singapore (Malay), which plays mostly a symbolic role. The Constitution of Singapore designates Malay as the national language because Malays are constitutionally recognized as the indigenous peoples of Singapore, and it is the government's duty to protect their language and heritage. Also according to the constitution, the four commonly used languages of Singapore are English, Chinese, Malay and Tamil.

2 By "formal language" we mean a language variety used in formal (solemn, serious, respectful, conventional, etc.) situations, e.g., ceremonies, academic articles, news reports, books, legal documents, business letters, etc. In contrast, "informal language" is used in informal situation; e.g., parties, meetings among friends, casual letters, conversations, etc.

3 An indigenous language is a language that is native to a particular area, community or region. It is spoken by people who originate there. 
English, which is used for formal topics. Vagle (1991) also showed that language in radio is a mixture of spoken and written language and that the social variables that determine the speech styles in radio situations are not the same as those in other situations. Actually, language in radio is not fixed. McFarland (2004) says that it is highly variable and changeable. Marina (2014) discovered that in urban Java, colloquial Indonesian or Javanese was used instead of standard (Jakartan) Indonesian on radio broadcasts. Some studies also relate radio styles to language standardization and purism. For example, Nefedov (2017) studied ungrammatical features in Russian speech on the radio and suggested that the language of radio in Russia is clean and represents high culture for the population. Rožukalne (2016) also showed that Standard Russian is considered to be the most prestigious and most powerful radio language in Latvia.

The second group of past studies on radio and language argue for the use of local or indigenous languages and vernacular varieties 4 instead of standard or national languages. The most common reason given is for the benefits of the people in the community. Frazier et al. (2012) and Dweik and Qawar (2015) show how effective the use of Spanish is in radio for Hispanic people in the United States as it helps reduce risk factors for various diseases. Another reason provided by such studies is that the use of local language helps foster the identities of minority groups or revitalize indigenous languages including for example: the promotion of Basque-language radio in Europe (Agirreazkuenaga 2012), the establishment of indigenous language radio broadcasting in Zimbabwe (Mabika \& Salawu 2014), the popular use of local dialects in Thai community radio even though many listeners do not understand the language of community radio (Magpanthong \& McDaniel 2015), the use of nativized Black South African English (BSAE) in community radio in South Africa (Makalela 2013), and the promotion of the use of Irish English varieties in Ireland's radio advertising (O'Sullivan 2013; Hickey et al. 2017).

In contrast to the concern about purism and standard usage, codeswitching 5 in radio broadcasts is another topic of past research. Ranasuriya (2015) shows that English-Singhalese code-switching, which is considered to be non-standard, exists in radio programs in spite of people's awareness of language purism. Zipp (2017) studies Gujarati-English code-switching in the media and points out that it signifies the linguistic negotiation of local and

4 A vernacular language means a language or a language variety spoken naturally as one's mother tongue. It is not learned or acquired formally in school.

5 Code-switching means alternate use of two or more languages in a conversation. This concept will be dealt with in more detail in the results part. 
transnational influences. In addition, code-switching is also found on the radio in: the Philippines (Rubino 2006), the Republic of Ireland (Atkinson \& Kelly-Holmes 2011), South Africa (Bosch \& Mullins 2012) and in Arab Canadian communities in Quebec (Dweik and Qawar 2015). Dweik and Qawar (2015) found that people use Arabic language in the home and religious domains and when listening to the radio, but use English and French in governmental offices and educational institutions.

A few previous studies dealt with the use of national language and identity on radio. Brown et al. (2017) focuses on creating a unique identity of Kazakhstan by establishing the Kazakh language as a radio language. The use of Kazakh must be in at least $5^{\circ}$ per cent of all the broadcast programs. This is to lessen the dominance of Russian on the radio. Nijhawan (2016) goes back in history to probe the establishment of the national language of India. The article shows debates over radio broadcasting in All India Radio's Lucknow station in 1938 so as to determine which language, among Hindi, Urdu and Hindustani, was to be the official national language.

Countering the use of national or standard language on the radio is the increasing use of English, which may be observed in the increase of codeswitching between English and the local language, as mentioned above. Actually, Tanaka (1995), Rubino (2006), and Muhonen (2010) show that English has played an increasingly greater role on the radio in Japan, the Philippines and Finland, respectively. In Thailand, English has been influential in the domain of media for several decades, as Masavisut et al. (1986) shows evidence of its remarkable influence in advertising in Thai media including radio in the 1980's. This seems to be an important issue but it seems that previous studies on the role of English in radio in non-English-speaking countries are rare, particularly those concerning Southeast Asia.

\section{Data Collection}

\subsection{Sources of Data}

Sources of data were obtained by searching the internet with the Google web search engine and using the name of each of the ten countries plus the word "radio;" for example, such search terms as Brunei radio, Cambodia radio, Indonesia radio, Laos radio, Malaysia radio, Myanmar radio, Philippines radio, etc.

A few websites were found that lead to every country's radio, but we chose one that was the most effective and easiest to use. The address is http://www liveonlineradio.net., and a sample webpage is shown in Figure 1. 


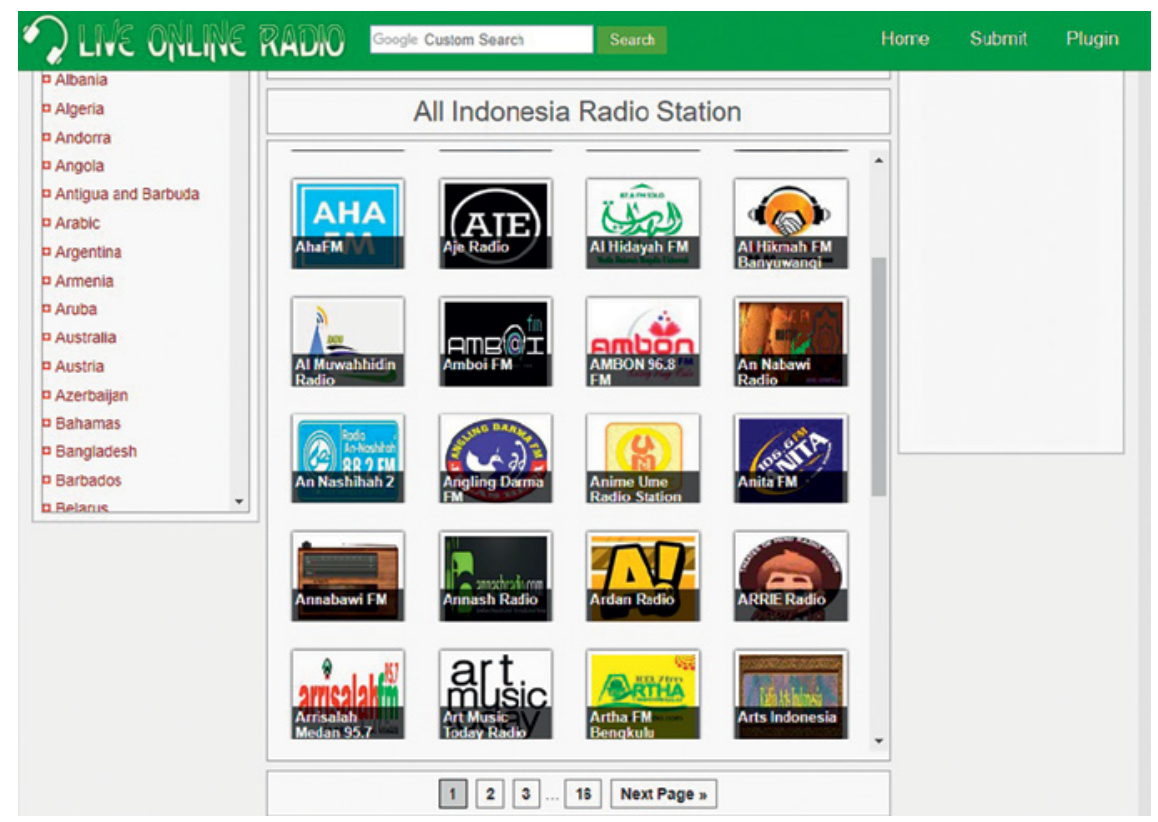

FIGURE 1 Webpage from http://www.liveonlineradio.net

From this website ${ }^{6}$ we were able to listen to live radio broadcasts from a particular country. Figure 2 shows a webpage with a list of Indonesia radio stations on the left-hand column from which we could click to listen to each one.

It happened that not all the ten ASEAN countries could be reached via the above-mentioned website. Three countries (Laos, Myanmar and Brunei) we had to access via other websites as follows:

Laos radio: https://lnr.org.la/

Myanmar radio: http://www.myanmartvchannel.com/radio.html Brunei radio: http://www.rtb.gov.bn/SitePages/Net\%2oRadio.aspx

\subsection{Data Sampling}

After a few surveys into the webpages of all the countries in focus, we decided to collect data from a sample of talk programs during 6.00-8.00 and 11.00-13.00 (Greenwich Mean Time) or 13.00-15.00 and 18.00-20.00 (Thailand time $)^{7}$ every

6 It should be noted that this website uses English as a lingual franca. The names of countries and radio stations are written in English. This is a good proof that English is the most preferred global language.

7 These two blocks of time (13.00-15.00 and 18.00-20.00) are the same as in Indonesia, Cambodia, Laos, and Vietnam, but equal 14.00-16.0o and 19.00-21.0o in Singapore, Philippines, Malaysia, and Brunei, and become 12.30-14.30 and 17.30-19.30 in Myanmar. 


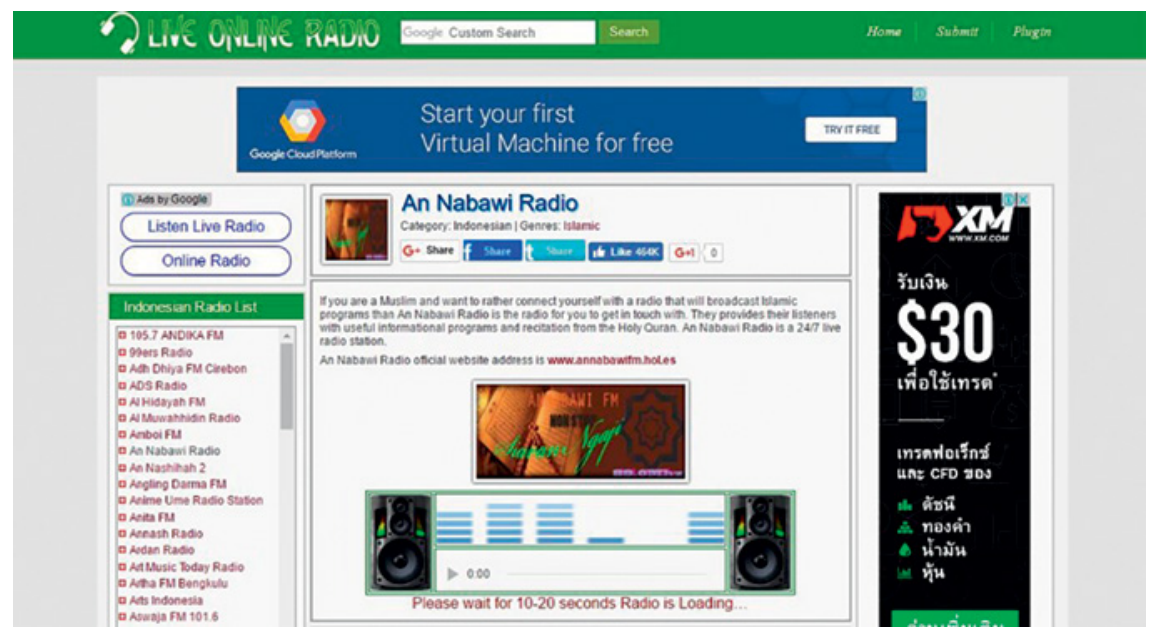

FIGURE 2 A sample webpage showing Indonesia's list of radio stations

day for three weeks. The reason for choosing those two blocks of time is that talk programs were broadcast most during that time. During the other times, programs that we did not want, e.g., music programs, were found more. We tried to visit every station that could be accessed and listened to 1-3 programs in each station until we covered all the stations country by country. ${ }^{8}$ Idealistically, we planned to devote about two days to each country. However, it turned out that the amount of time spent on collecting data from each country was not equal. Three factors determined the amount of data we could collect from each country: the speed of the internet, how fast we could identify each language, and the speed with which we could note down all the information we needed. Consequently, we had much more data from Thailand than any other country because as native speakers of Thai, we could collect the data faster and more easily and in less time.

In addition, we selected only data of "talk" of all kinds (See Table 1 for the categories of talk data we collected.) and excluded music programming. Another condition for data selection is that all stations that belong to foreign countries were excluded, such as BBC, CNN. We also planned to exclude community radio stations because they would be likely to use dialects or ethnic languages, which were not within the scope of this study. Community radio stations were also self-excluded because none of them could be reached via

8 The numbers of radio stations in all ten countries are not equal, and the numbers of those accessible are also different. We planned to spend at least five minutes listening to each stations. However, in case there were difficulties, we spent more than five minutes. 
the websites we had chosen. Our focus was on English and the national language of each country.

\subsection{Recording Data}

The data was noted down while we were listening to live radio broadcasts from each country. It should be noted that all ten countries have different numbers of radio stations. Laos has the least (only one station). Indonesia has the most (we reached 32 stations). ${ }^{9}$ We attempted to visit as many stations as possible in the limited selected periods of time ( 2 two-hour blocks) per day until we completed accessing all the available stations. The recorded data was composed of the following information:

1) Name of the country

2) Name of the radio stations (See the table of each country in the appendix.)

3) Type of the program (See details below and in Table 1.)

4) Language: We focus on English and the national language. Other languages that were used were classified as "other language." If more than one language were used, we classified it as "code-switching." Details about language use are presented in the results section. It should also be noted that our proficiency of each of the national languages is low except that of Thai, our native language. However, in the data collection, we were able to identify all major languages from the talk in a program we were listening to, but we did not understand the content of the program, which is beyond the scope of this study. As for some minor languages beside the national languages, we got some clues which indicated what language it was, e.g., the speaker announced the name of the language. In cases where we could not figure out at all what language we were listening to, we would label it as "unspecified." Moreover, since this study focuses on the generic level of "language," it does not take into account language varieties; for example, English is not identified in detail as "Thai English," "Singaporean English," "formal English," or "informal English," etc. In sum, we differentiate languages, not dialects or styles.

5) Other information: We noted down source of data, topic, gender of participants, and some paralinguistic features, e.g., loudness, rate of speech. Even though some parts of the information were not taken into account

9 It should be noted that the fewer stations we reached, the larger the number of programs we listened to and vice versa. This approach balanced out the numbers of programs for each country. 
TABLE 1 Types of the radio programs in ASEAN countries

\begin{tabular}{|c|c|c|c|c|c|c|c|}
\hline \multirow[t]{2}{*}{ Country } & \multicolumn{6}{|c|}{ Show type } & \multirow[t]{2}{*}{ Total } \\
\hline & 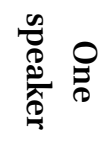 & $\sum_{i}^{\infty}$ & $\sum_{\infty}^{Z}$ & $\frac{\infty}{\stackrel{n}{o}}$ & 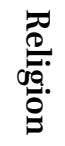 & 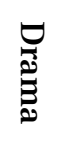 & \\
\hline Brunei & 54 & 9 & & & & & 63 \\
\hline Cambodia & 10 & & 3 & & & & 13 \\
\hline Indonesia & 14 & 14 & 3 & & & 1 & $3^{2}$ \\
\hline Laos & 13 & 1 & 1 & & & & 15 \\
\hline Malaysia & 12 & 4 & & & & & 16 \\
\hline Myanmar & 50 & 2 & & & 6 & & $5^{8}$ \\
\hline Philippines & 15 & 4 & 1 & & & & 20 \\
\hline Singapore & 5 & 5 & 2 & & & & 12 \\
\hline Thailand & 10 & 85 & 36 & 10 & & & 141 \\
\hline Vietnam & 5 & 2 & 3 & & & & 10 \\
\hline Total & 188 & 126 & 49 & 10 & 6 & 1 & 380 \\
\hline
\end{tabular}

in the quantitative analysis, they were useful when we interpreted the data qualitatively.

Regarding the types of the programs, we classified all the accessed programs into six broad types:

1) One speaker: any kind of show with only one speaker, e.g., lectures, announcements, narratives, and DJ's talk

2) Talk show: any kind of show involving more than one speaker, mostly the host and the guest (s) and optionally a listener who phones in.

3) News: news presentations

4) Sports: sport announcements

5) Religion: programs showing religious talk or ceremonies

6) Drama: radio dramas

Table 1 shows the numbers of each type of the radio programs found in the data. It should be noted that Thailand has the largest number of programs in the sample. This is because we could access most stations and programs more easily and clearly than those in the other counties. 


\section{Results of the Analysis}

\subsection{Patterns of Radio Language in ASEAN Countries}

The results of the analysis show that the languages in radio broadcast programs in ASEAN countries can be classified into four categories: English, National language, Other language, and Code-switching.

\section{a) English}

This category refers to radio language where only English is used. The category "English" is used broadly here to refer to any variety of English used in radio programs. Actually, the data show some variation in English used on radio in ASEAN countries. In the news programs, the English variety that is used seems to be Standard British English or Standard American English. However, in talk shows, localized varieties of English are found to be used, e.g., Singaporean English, Filipino English, etc.

\section{b) National language}

This category refers to the national language of each ASEAN country. The term is also used broadly without regard to its varieties. The data of language use on radio in Thailand show that that there is more stylistic variation than sociological (or "speaker") variation. In other words, the radio shows in Thailand have a tendency to shift styles or registers according to program difference, but it is very rare to find speakers' shifting dialects, except gender dialects, which are partly controlled by grammar. For instance, in Thai, the speakers have to use pronouns and final particles appropriate for their gender. However, it seems that social class and ethnic group variation was unnoticeable.

\section{c) Other language}

"Other language" refers to any language that is neither English nor the national language. In cases where we could identify a language, we would specify it, but if not, we would label it as "unspecified." In general, we found very few incidences of the "unspecified" category. Other languages we found included: Mandarin, Tamil, Nepali and a few unspecified languages.

\section{d) Code-switching}

Code-switching here refers to any kind of mixing two languages, whether intra-sentential or inter-sentential. Code-switching was found in radio programs in five countries: Brunei, Indonesia, Philippines, Singapore, and Thailand. 


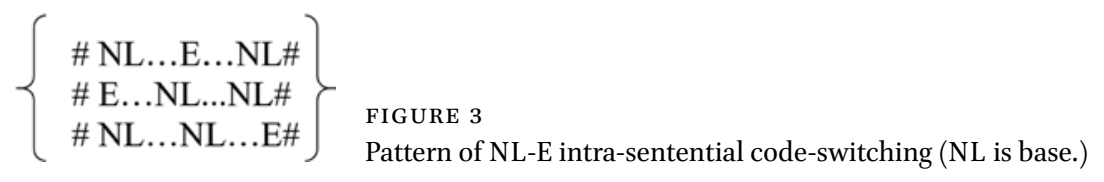

$$
\left\{\begin{array}{l}
\# \text { E...NL...E\# } \\
\# \text { NL...E...E \# } \\
\# \text { E...E...NL \# }
\end{array}\right\} \begin{aligned}
& \text { FIGURE } 4 \\
& \text { Pattern of E-NL intra-sentential code-switching (E is base.) }
\end{aligned}
$$

The data indicate that most cases of code-switching are intra-sentential, as in the following examples.

\subsection{Examples of Intra-Sentential Code-Switching}

The pattern of intra-sentential code-switching found in this study is mixing English words in sentences in an ASEAN national language, and the other way around; i.e., mixing words from ASEAN national languages in English sentences. In the former, an ASEAN national language functions as the base language in intra-sentential code-switching. In the latter, English is the base language. This pattern is found much less than the former, probably due to the fact that more programs use national languages (NL) rather than English. ${ }^{10}$ The intra-sentential code-switching patterns may be represented by Figures 3 and 4.

The sign \# signifies a sentence boundary. The pattern represented by Figure 3 is that English words appear in the middle, at the beginning or at the end of the sentence filled with words in an ASEAN national language. The pattern in Figure 4 is similar, but the base language is English. In the following examples, we specify only English words, but indicate what NL is.

\section{Brunei:}

NL-E intra-sentential code-switching: \# Malay...straight...Malay \#

1o We did not find code-switching between English and other minor languages in the data. vv. 
\# Malay...Malay...right now. \#

\# The mini-concert...Malay...Malay.\#

E-NL intra-sentential code-switching (Only one utterance is found):

\# Okay, so we now...Malay \#

\section{Indonesia:}

NL-E intra-sentential code-switching:

\# Indonesian...night...Indonesian\#

\# The job fair...Indonesian...Indonesian\#

\# Indonesian...Indonesian...home \#

E-NL intra-sentential code-switching: No occurrence

\section{Philippines:}

NL-E intra-sentential code-switching:

\# Filipino...of course...Filipino \#

\#Government...Filipino...Filipino \#

\#Filipino...Filipino...thankyou. \#

E-NL intra-sentential code-switching:

\# Well, that's so...Filipino \#

\# After this, I will...Filipino \#

\# Filipino...may happen again \#

\section{Thailand:}

NL-E intra-sentential code-switching:

\#Thai... big data ...Thai\#

\#AI...Thai...Thai \#

\# Thai...Thai...unlocking our future\# 


\section{E-NL intra-sentential code-switching: No occurrence}

Singapore: No intra-sentential code-switching is found.

\subsection{Examples of Inter-Sentential Code-Switching}

Inter-sentential code-switching here means alternate use of English and national language sentences. In this study only two countries are found to have this pattern of code-switching in their radio languages, Singapore and the Philippines.

Singapore has inter-sentential code-switching on radio in the form of English-Mandarin switching. Even though, Mandarin is not the national language, it is one of the official languages of Singapore and seems to be second to English in its importance. For example:

\# Mandarin \#,,\#That's not what we expected.\#...

As for the Philippines, inter-sentential code-switching is found in both English programs or Filipino programs. The speakers seem to be natural in switching between English and Filipino sentences. For example:

- \# When you talk about it, I would say this \# ... \# Filipino \#...

- \#Filipino\#...\#How come it turned out like that.\#...

Concerning code-switching on the radio in ASEAN countries, we can summarize that intra-sentential patterns are used much more than inter-sentential patterns and that it seems to appear only in the two countries that use English most on radio (Singapore as No.1, and Philippines as No. 2, as shown in Figure 3).

\subsection{Frequencies of Patterns of Radio Languages in ASEAN Countries}

In order to determine the degree of the use of particular languages in radio broadcasts in ASEAN countries, we counted the radio stations that use English only in broadcasting, those that use the national language only, those that use other languages, and those that use code-switching (national language mixed with English). The result is shown in Table 2 and Figure 5 below.

Since the focus of this study is the use of English across the ten ASEAN countries, we ordered the percentages according to the use of English, which is presented in Figure 5. As can be seen, Singapore uses English most on radio and it does not use the national language (Malay). The Philippines is the second 
TABLE 2 Percentages of the use of English and National language in ASEAN radio programs (Alphabetically ordered according to country names)

\begin{tabular}{|c|c|c|c|c|c|}
\hline \multirow[t]{2}{*}{ Country } & \multirow{2}{*}{$\begin{array}{c}\text { No. of } \\
\text { programs }\end{array}$} & \multicolumn{4}{|c|}{ Language } \\
\hline & & English & $\begin{array}{l}\text { National } \\
\text { language }\end{array}$ & Other & $\begin{array}{l}\text { Code- } \\
\text { switching }\end{array}$ \\
\hline Brunei & 63 & $7(11.11 \%)$ & $46(73.01 \%)$ & $\begin{array}{l}3 \text { unspecified }(4.76 \%) \\
2 \text { Nepali }(3.17 \%) \\
1 \text { Mandarin }(1.59 \%)\end{array}$ & $4(6.35 \%)$ \\
\hline Cambodia & 13 & $\mathrm{o}(\mathrm{o} \%)$ & $13(100 \%)$ & $\mathrm{o}(\mathrm{o} \%)$ & $o(0 \%)$ \\
\hline Indonesia & 32 & $2(6.25 \%)$ & $28(87.5 \%)$ & $o(0 \%)$ & $2(6.25 \%)$ \\
\hline Laos & 15 & $\mathrm{o}(0 \%)$ & $15(100 \%)$ & о $0 \%)$ & $\mathrm{o}(0 \%)$ \\
\hline Malaysia & 16 & $2(12.5 \%)$ & $9(56.25 \%)$ & 5 Mandarin $(31.25 \%)$ & o $(0 \%)$ \\
\hline Myanmar & $5^{8}$ & $o(0 \%)$ & $5^{8}(100 \%)$ & $o(0 \%)$ & o $(0 \%)$ \\
\hline Philippines & 20 & $4(20 \%)$ & $10(50 \%)$ & $\mathrm{o}(\mathrm{o} \%)$ & $6(30 \%)$ \\
\hline Singapore & 12 & $6(50 \%)$ & $0(0 \%)$ & $\begin{array}{l}3 \text { Tamil }(25 \%) \\
2 \text { Mandarin }(16.67 \%)\end{array}$ & $1(8.33 \%)$ \\
\hline Thailand & 141 & $5(3.55 \%)$ & $133(94.33 \%)$ & $\mathrm{o}(\mathrm{o} \%)$ & $3(2.12 \%)$ \\
\hline Vietnam & 10 & $o(0 \%)$ & $10(100 \%)$ & o $(0 \%)$ & $o(0 \%)$ \\
\hline
\end{tabular}

in using a high degree of English. In contrast, Laos, Myanmar, Cambodia and Vietnam do not use English at all on radio. In other words, these countries have no radio station that broadcasts in English only. Instead, they use their national languages $100 \%$. If we focus on the "code-switching" pattern, we can see that the Philippines is the top (30\%). This finding supports Rubino (2006), who found that code-switching was used to a considerable extent on the radio in the Philippines.

From Figure 5, it is convenient to summarize the degree of using each pattern of radio language in all ASEAN countries in terms of ranking them by using the sign > which means 'more than', as follows.

\section{Using English on the radio from most to least:}

Singapore $>$ the Philippines $>$ Malaysia $>$ Brunei $>$ Indonesia $>$ Thailand $>$ Vietnam $>$ Cambodia, Laos, Myanmar

\section{Using the national language on the radio from most to least:}

Myanmar, Laos, Cambodia $>$ Vietnam $>$ Thailand $>$ Indonesia $>$ Brunei $>$ Malaysia $>$ the Philippines $>$ Singapore 


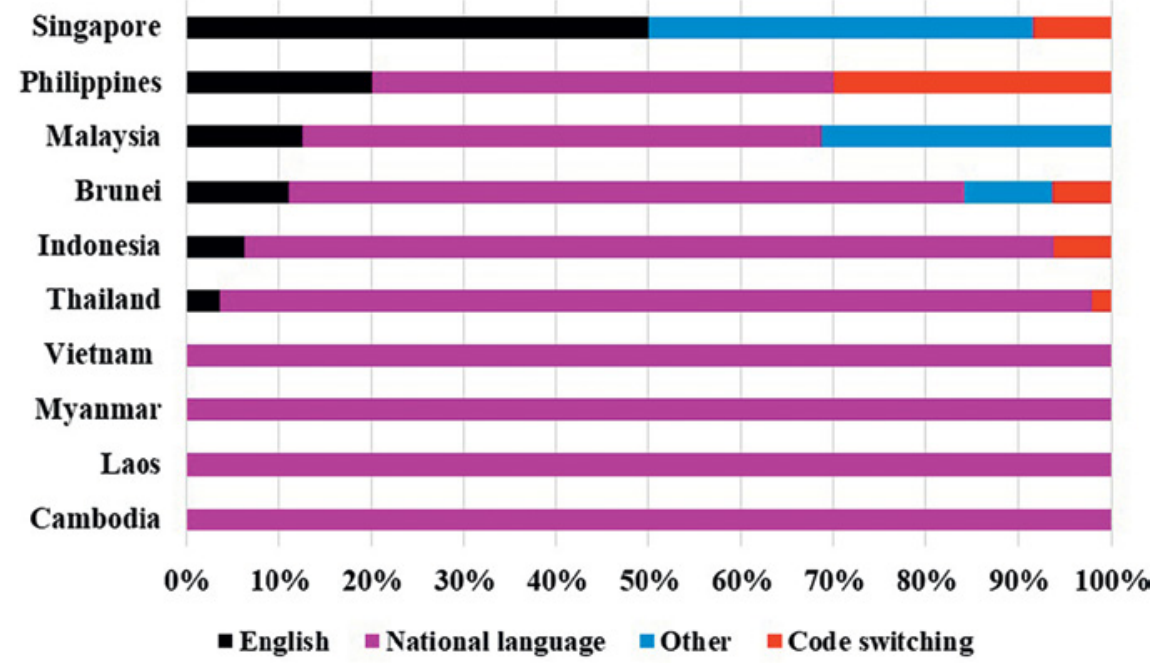

FIGURE 5 Radio languages in ASEAN countries

Using code-switching on the radio from most to least:

The Philippines $>$ Singapore $>$. Brunei $>$ Indonesia $>$ Thailand $>$ Malaysia, Cambodia, Myanmar, Laos

\section{Discussion and Conclusion}

This study focuses on the use of English and the national language on the radio in the ten ASEAN countries: Brunei, Cambodia, Indonesia, Laos, the Philippines, Malaysia, Myanmar, Singapore, Thailand and Vietnam. It aims to find out how much English and the national language are used as the radio language in this region and present a picture of it without taking into account such features as the content of the radio programs and linguistic features such as: grammatical errors, stylistic markers, and standardized accents. From the results of the analysis, it can be concluded that among the ten countries, there are four countries that never use English in radio broadcasts: Laos, Cambodia, Vietnam and Myanmar. The rest show different degrees in the use of English on the radio. Singapore uses English most in radio broadcasts. This may be because English is one of the four official languages of the country (English, Malay, Mandarin, and Tamil). Beside Singapore, the results certainly support our hypothesis that the national language is used more than English as radio language. The evidence is that in nine out of the ten ASEAN countries, the national language is used more than English on the radio. From this, it is safe to 
say that English has not taken over the domain of this mass medium in these countries.

This finding may be unanticipated to some who hold on to the fact that English is legally the working language of ASEAN as a whole. It is probably due to two reasons. First, English serves as the lingua franca of ASEAN countries. The leaders of those countries use English in ASEAN meetings. In other words, English is used outside each country, but not necessarily within, as shown in the findings that it functions as a radio language in only some countries. Secondly, the fact that radio is a very common and cheap type of mass media implies that radio language has to be the language most people in the society understand. Of course, the national language of a country serves to most extents as a lingua franca within the country. That is why it is found in this study that national language is used much more than English on the radio.

There are several social variables that distinguish each of the ten countries in terms of language use on radio. Firstly, colonialism may be related to the finding that Vietnam, Cambodia, and Laos do not use English at all on radio while Singapore, the Philippines, Malaysia and Brunei use English more on radio. The former group are former French colonies while the latter are former British and American colonies. As for Myanmar (formerly Burma), even though it was a British colony, the findings show that English does not appear on radio. This may be because at some periods in history ${ }^{11}$ Myanmar went through isolation due to economic sanctions from the west, to the extent that schools and universities were closed down for a while. This situation might affect the current level of both the English proficiency of the citizenry and opportunities for use of an international language. This may be related to the fact that Myanmar does not use English at all on radio. Secondly, language policy seems to explain why Malaysia uses English on radio less than Singapore. Malaysia has changed their language policy several times in the past half century, resulting in a disruption in the teaching and use of English. Finally, the status of English as an "official language" also corresponds with the high end of English radio usage.

From the point of view of national languages, the strong link between the radio and a national language can be inferred from the findings of this study. Indeed, only Singapore was found to have the national language (Malay) missing on radio, while English is mainly used. It is clear that Malay serves as a symbol, not a practical language in Singapore. For the rest of the countries, the national language is the major radio language. This seems to have two

11 From the 1990's to the 2020's ( https://en.wikipedia.org/wiki/Myanmar). 
advantages: 1) It is an effective medium that enables the majority of people to understand the content it conveys, 2) it fosters the sense of nativeness or indigenousness and identity, as suggested by Brown et al. (2017) mentioned above.

Another point that requires further explanation here is the relationship between the radio languages and types of programs. The data reveal that among these categories of the programs: One speaker, Talk show, News, Sports, Religion, Drama, the national language is found in all and that English is used in News and some talk shows. English seems to be related to the "formal" feature of the radio, but the national language can be used in both formal and informal programs.

To sum up, radio deals with conveying content or information to the listeners. It is the most convenient mass medium in terms of accessibility. The findings of this study enable us to see a broad picture of language choice on radio in ASEAN countries, which can be summarize as follows.

1) The national language is the major radio language in ASEAN countries. It is used in all kinds of programs. When English is used, it is used primarily in news shows. The rest (non-national languages) are found in "One speaker" program only. Since news programs are more formal than others, it is safe to say that English is probably regarded as more formal than national languages.

2) Code-switching was found in five countries occurring in all programs except news. This suggests that code-switching is not a formal pattern of language use. Intra-sentential code-switching is more common than inter-sentential pattern in ASEAN countries. Only the countries that have a high degree of the use of English on radio use inter-sentential code-switching.

3) The findings imply that there is a strong connection between the national language and the population of the nation. Practically, the use of the national language as the radio language facilitates communication because the message is conveyed by the language of the local people. Symbolically, it reinforces national unity and promotes national identity. However, this does not apply to Singapore. It is the only country that does not use its national language on radio. If we conclude from the majority that the national language is the radio language, then English, which appears most frequently on radio in Singapore, seems to play the role of the national language of this country.

4) Further studies may focus on the use of styles and dialects or vernacular languages on radio in ASEAN countries. That may reveal a more complete picture of language use on radio in Southeast Asia. 


\section{Acknowledgements}

The earlier version of this article was presented at the seminar on "English vs. Thai, Which One Wins? The Competition between the World Language and the National Language in the Globalizing World," at the Faculty of Humanities, Kasetsart University, Bangkok, Thailand, on 24 May 2017. We are very grateful to Dr. Thom Huebner and Dr. Andrew Jocuns for their insightful comments and suggestions, which help improve this article. We are also thankful to the Thailand Research Fund for a "Distinguished Research Professor Grant," which supports our conducting research and disseminating the findings.

\section{References}

Agirreazkuenaga, I. 2012. The Role of the Media in Empowering Minority Identities: Basque-Language Radio During the Franco Dictatorship (1960s-1976) and Their Influence as Identity Catalysts. Media, Culture \& Society 34.5: 498.

Atkinson, D. \& H. Kelly-Holmes. 2011. Code-Switching, Identity and Ownership in Irish Radio Comedy. Journal of Pragmatics 43.1: 251-260.

Bosch, T. E. \& C. Mullins. 2012. Radio, Race and Identity in South Africa: The Case of Metro FM.Journal of Radio \& Audio Media 19.1: 110-122.

Brown, M., A. Yerkimbay, K. Myssayeva. 2017. Radio and the Development of Kazakh as a National Language. Journal of Radio \& Audio Media 24.1: 161-175.

Dweik, B. S. \& H. A. Qawar. 2015. Language Choice and Language Attitudes in A Multilingual Arab Canadian Community: Quebec-Canada: A Sociolinguistic Study. British Journal of English Linguistics 3.1: 1-12.

Fishman, J. A. 1991. Reversing Language Shift: Theoretical and Empirical Foundations of Assistance to Threatened Languages. Clevedon, England: Multilingual matters.

Frazier, M., S. Massingale, M. Bowen, \& C. Kohler. 2012. Engaging a Community in Developing an Entertainment-Education Spanish-Language Radio Novella Aimed at Reducing Chronic Disease Risk Factors, Alabama, 2010-2011. Preventing Chronic Disease 9: 110344 (pp.1-9).

Hickey, R., E. Vaughan, J. O'Sullivan, H. Kelly-Holmes. 2017. Vernacularisation and Authenticity in Irish Radio Advertising. World Englishes 36.2: 269-282.

Mabika, M. \& A. Salawu. 2014. A Tale of Failure: Indigenous Language Radio Broadcasting in Zimbabwe. Mediterranean Journal of Social Sciences 5.2: 2391-2401.

Magpanthong, C. \& D. McDaniel. 2015. The Audience for Thailand's Booming Community Radio System. Journal of Radio \& Audio Media 22.1: 60-76.

Marina, M. \& K. Domagoj. 2014. FM Radio and Youth: Listeners or Users?. Medijske Studije 5.9: 61-75. 
Makalela, L. 2013. Black South African English on the radio. World Englishes 32.1: 93-107. Masavisut, N., M. Sukwiwat and S. Wongmontha. 1986. The Power of the English Language in Thai Media. World Englishes 5.2-3: 197-207.

McFarland, A. M. 2004. Creating A National Passion: Football, Nationalism, and Mass Consumerism in Modern Spain. PhD dissertation. University of Texas at Austin.

Muhonen, A. 2010. "It's a vicious circle": The Roles and Functions of English in Sweden Finnish Youth Radio Programs. Journal of Finnish Studies 14.2: 1-17.

Nefedov, I. V. 2017. Russian Speech in Radio: Norm and Deviation. Izvestiâ Úžnogo Federal'nogo Universiteta: Filologičeskie Nauki 2017.2: 118-126.

Nijhawan, S. 2016. Hindi, Urdu or Hindustani? Revisiting 'National Language' Debates through Radio Broadcasting in Late Colonial India. South Asia Research 36.1: 80-97.

O'Sullivan, J. 2013. Advanced Dublin English in Irish Radio Advertising. World Englishes 32.3: $35^{8-376 .}$

Ranasuriya, D. 2015. Effects of Radio and Television Media on Language. Journal of Mass Communication and Journalism 5: 265 (pp.1-6).

Rožukalne, A. 2016. 'All the Necessary Information is Provided by Russia's Channels'. Russian-language Radio and TV in Latvia: Audiences and Content. Baltic Screen Media Review 4: 106-124.

Rubino, C. 2006. Philippines: Language Situation. In Encyclopedia of Language and Linguistics, edited by Keith Brown, pp. 323-326. London: Elsevier.

Tanaka, S. O. 1995. The Japanese Media and English. World Englishes 14.1: 37-53.

Vagle, W. 1991. Radio Language - Spoken or Written?. International Journal of Applied Linguistics 1.1: 118-131.

Zipp, L. 2017. Code-Switching in the Media: Identity Negotiations in a Gujarati Diaspora Radio Program. International Journal of the Sociology of Language 247:33. 


\section{APPENDIX}

Occurrences of patterns of Language used in radio programs in ASEAN countries ordered alphabetically from 3.1 to 3.10

TABLE 3.1 Brunei

No. Name of station Language used in programs

TOTAL

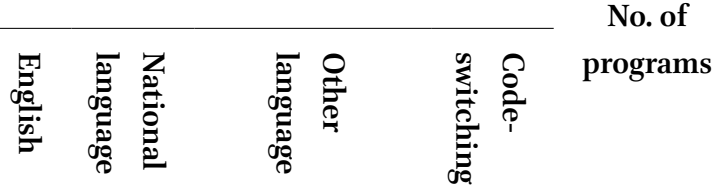

1. Nasional FM(92.3

13

13

93.8FM)

2. Pilihan FM(95.6

7

3 unspecified

13

96.9 FM)

2 Nepaliı

Mandarin

3. $\quad$ Pelangi $(94.491 .0$

9

4

13

FM)

4. Harmoni $\mathrm{FM}(94.1$

12

12

97.7 FM)

5. $\quad$ Nur Islam (93.3 94.9

12

12

FM)

Frequencies of

$\begin{array}{lll}7 & 46 & 6\end{array}$

4

63

language use 
TABLE 3.2 Cambodia

\begin{tabular}{|c|c|c|c|c|c|}
\hline \multirow[t]{2}{*}{ No. } & \multirow[t]{2}{*}{ Name of station } & \multicolumn{3}{|c|}{ Language used in programs } & TOTAL \\
\hline & & 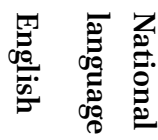 & 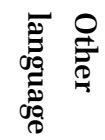 & 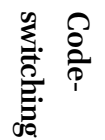 & programs \\
\hline
\end{tabular}

1. Radio Cambodia RNK AM

2. (Radio National of

Kampuchea)

3. Sarika FM

4. Khmer Archive

5. The Khmer Post Archive

6. Hang Meas FM 104.5 MHz

7. Rasmey Hang Meas FM

95.7 $\mathrm{MHz}$

Daunpenh eFM Hit

8. Music Station 87.5 FM

Phnom Penh

9. Bayon Radio and

9. Television

10. VAYO FM

11. DaunPenh EFM

12. Tonle FM

RNK FM (Radio

13. National of Kampuchea)

Frequencies

of language use

1

1

1

1

1

1

1

1

1

1

1

1

1

1

1

$\begin{array}{lllll}\text { 0 } & 13 & \text { o } & \text { o } & 13\end{array}$ 
TABLE 3.3 Indonesia

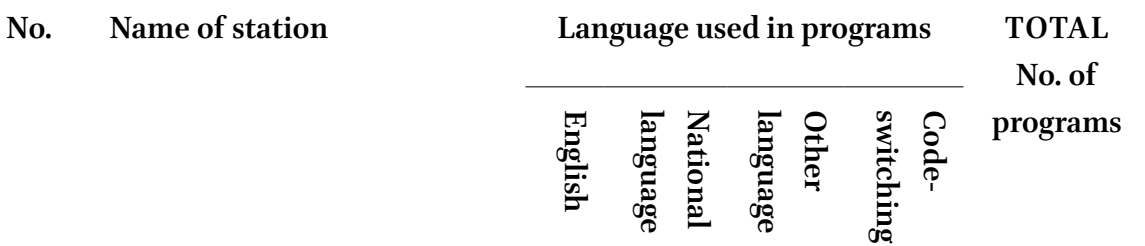

$\begin{array}{ll}\text { 1. } & \text { Adh Dhiya FM Cirebon } \\ \text { 2. } & \text { ADs Radio } \\ \text { 3. } & \text { Al Hidayah FM } \\ \text { 4. } & \text { Al Muwahhidin Radio } \\ \text { 5. } & \text { An Nabawi Radio } \\ 6 . & \text { Gen FM } \\ \text { 7. } & \text { Jak Fm } \\ \text { 8. } & \text { Ardan Radio 105.9 FM } \\ 9 . & \text { 105.7 ANDIKA FM } \\ \text { 10. } & \text { Aswaja FM 101.6 } \\ \text { 11. } & \text { B One FM Bengkulu } \\ \text { 12. } & \text { Camajaya FM 102.6 }\end{array}$

1

1

1

1

1

1

1

13. Cemerlang Radio

14. Cirebon Radio

15. CJDW FM

16. CRadio 93.4 FM

17. Dairi FM Cirebon

18. Delta FM Indonesia

19. Diah Rosanti FM

20. Dreamers Radio

21. EBS FM

22. Elgangga FM

23. Evolution Hits Radio

24. Gama FM Tegal

25. Gen FM

26. Gradiosta FM

27. Lite FM 105.8

28. PRO4RRI JAKARTA

29. Radio Elshinta

30. Radio Mara

31. She Radio 99.6FM

32. Voice of Indonesia

Frequencies of language use

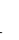

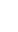


TABLE 3.4 LaOS

\begin{tabular}{|c|c|c|c|c|c|c|}
\hline \multirow[t]{2}{*}{ No. } & \multirow[t]{2}{*}{ Name of station } & \multicolumn{4}{|c|}{ Language used in programs } & \multirow{2}{*}{$\begin{array}{c}\text { TOTAL } \\
\text { No. of } \\
\text { programs }\end{array}$} \\
\hline & & 喟 & 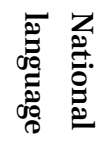 & 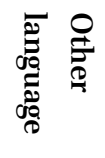 & 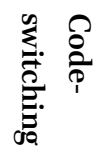 & \\
\hline \multirow[t]{2}{*}{1.} & $\begin{array}{l}\text { Lao National Radio FM } \\
103 \cdot 7\end{array}$ & & 15 & & & 15 \\
\hline & Frequencies of language use & $\mathbf{o}$ & 15 & $\mathbf{o}$ & $\mathbf{o}$ & 15 \\
\hline
\end{tabular}

TABLE 3.5 Malaysia

\begin{tabular}{|c|c|c|c|c|c|c|}
\hline \multirow[t]{2}{*}{ No. } & \multirow[t]{2}{*}{ Name of station } & \multicolumn{4}{|c|}{ Language used in programs } & \multirow{2}{*}{$\begin{array}{c}\text { TOTAL } \\
\text { No. of } \\
\text { programs }\end{array}$} \\
\hline & & 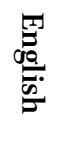 & 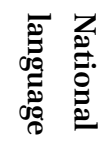 & 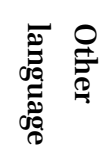 & 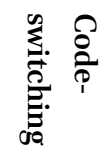 & \\
\hline
\end{tabular}

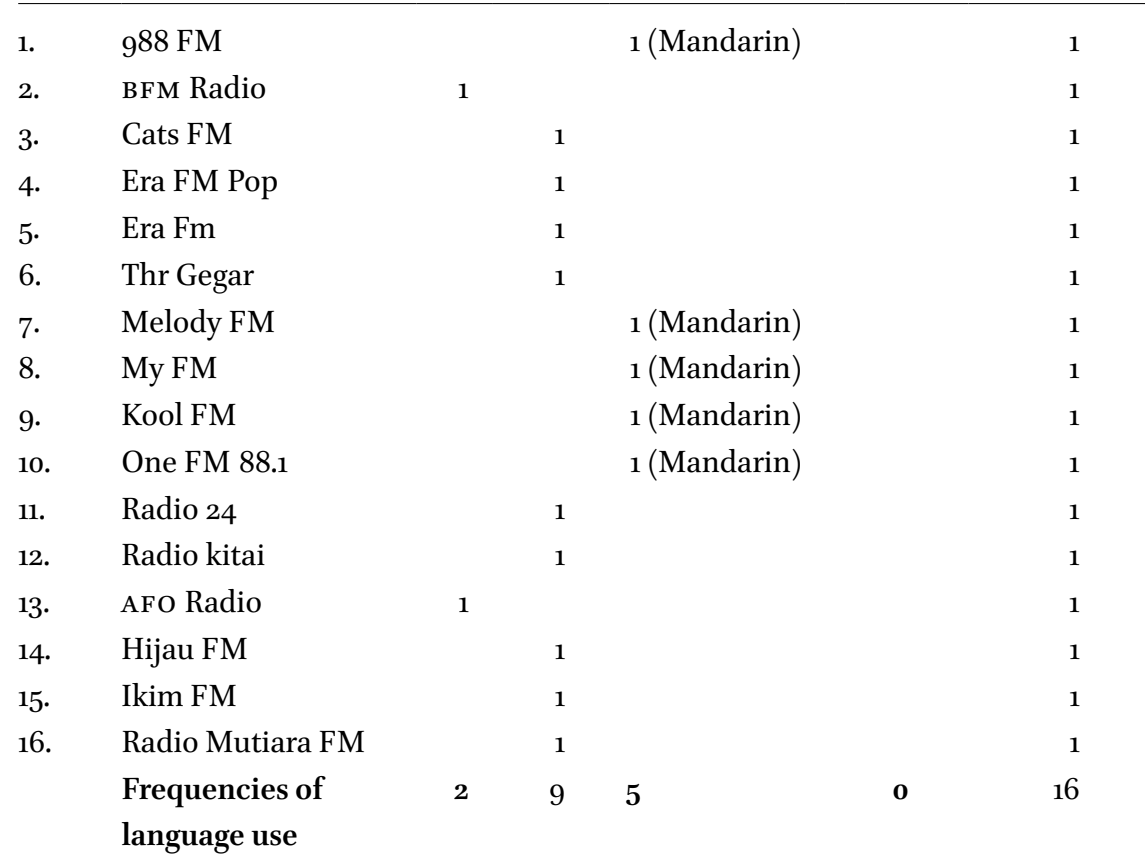


TABLE 3.6 Myanmar

\begin{tabular}{|c|c|c|c|c|c|c|}
\hline \multirow[t]{2}{*}{ No. } & \multirow[t]{2}{*}{ Name of station } & \multicolumn{4}{|c|}{ Language used in programs } & \multirow{2}{*}{$\begin{array}{c}\text { TOTAL } \\
\text { No. of } \\
\text { programs }\end{array}$} \\
\hline & & 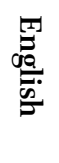 & 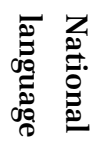 & 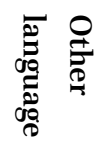 & 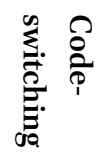 & \\
\hline 1. & Teen Radio & & 7 & & & 7 \\
\hline 2. & Mandalay FM & & 8 & & & 8 \\
\hline 3. & Padamyar FM & & 13 & & & 13 \\
\hline 4. & Cherry FM & & 5 & & & 5 \\
\hline 5 . & Thit sar parami & & 13 & & & 13 \\
\hline \multirow[t]{2}{*}{6.} & Tine Yin Thar & & 2 & & & 2 \\
\hline & Frequencies of language use & $\mathbf{o}$ & $5^{8}$ & $\mathbf{o}$ & $\mathbf{o}$ & $5^{8}$ \\
\hline
\end{tabular}


TABLE 3.7 The Philippines

\begin{tabular}{|c|c|c|c|c|c|}
\hline \multirow[t]{2}{*}{ No. } & \multirow[t]{2}{*}{ Name of station } & \multicolumn{3}{|c|}{ Language used in programs } & TOTAL \\
\hline & & 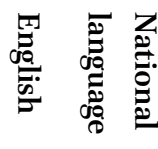 & 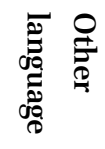 & 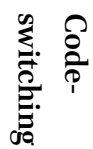 & programs \\
\hline
\end{tabular}

\begin{tabular}{|c|c|c|c|c|c|c|}
\hline 1. & DZRH News AM & & & & 1 & 1 \\
\hline 2. & Love Radio 90.7 & & 1 & & & 1 \\
\hline 3. & 702 Dzas & & 1 & & & 1 \\
\hline 4. & 92.3 News FM & & 1 & & & 1 \\
\hline 5. & 98.7 DZFE & 1 & & & & 1 \\
\hline 6. & Aksyon Radyo & & 1 & & & 1 \\
\hline 7 . & Barangay LS 97.1 & & & & 1 & 1 \\
\hline 8. & Bohol Radio & & 1 & & & 1 \\
\hline 9. & Dyrd Radio & & 1 & & & 1 \\
\hline 10. & MOR 101.9 & & 1 & & & 1 \\
\hline 11. & One Radio 91.3 FM & & & & 1 & 1 \\
\hline 12. & OPM Radio & & & & 1 & 1 \\
\hline 13 . & Pi Rocks & 1 & & & & 1 \\
\hline 14. & Pinoy Classic Songs & & 1 & & & 1 \\
\hline 15 . & Radyo 5 & & 1 & & & 1 \\
\hline 16. & $\mathrm{RB} 106$ & 1 & & & & 1 \\
\hline 17. & UNTV Radio & & & & 1 & 1 \\
\hline 18. & Xtreme Radio FM & & 1 & & & 1 \\
\hline 19. & Y101 FM & 1 & & & & 1 \\
\hline \multirow[t]{2}{*}{20.} & DZGM AM & & & & 1 & 1 \\
\hline & Frequencies of language use & 4 & 10 & $\mathbf{o}$ & 6 & 20 \\
\hline
\end{tabular}


TABLE 3.8 Singapore

No. Name of station

Language used in programs

TOTAL

No. of

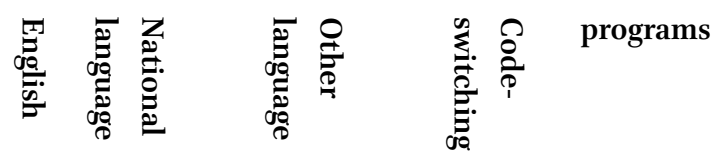

1. $\quad 88.3$ Jia FM

2. $\quad 938$ LIVE

3. Capital 95.8 FM

4. Gold 90.5FM

5. Kiss92

6. Love 97.2FM

7. Naga FM

8. Ria $89.7 \mathrm{FM}$

9. Class $95 \mathrm{FM}$

10. Hot FM 91.3

11. One FM 91.3

12. Oli $96.8 \mathrm{FM}$

Frequencies

of language use
1

1

1

1(Mandarin)

1

1

1

1

1(Mandarin)

1(Tamil)

1(Tamil)

1

1

1

1

1

1

1

1

1

12 
TABLE 3.9 Thailand

\begin{tabular}{|c|c|c|c|c|c|c|}
\hline \multirow[t]{2}{*}{ No. } & \multirow[t]{2}{*}{ Name of station } & \multicolumn{4}{|c|}{$\begin{array}{c}\text { Language used in } \\
\text { programs }\end{array}$} & \multirow{2}{*}{$\begin{array}{c}\text { TOTAL } \\
\text { No. of } \\
\text { programs }\end{array}$} \\
\hline & & 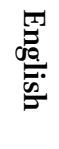 & 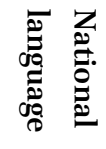 & 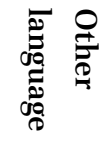 & 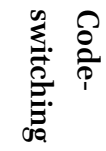 & \\
\hline
\end{tabular}

1. Radio Thailand

2. Cat Radio

$4 \quad 4$

3. EFM 94

4

4

4. Green Wave

4

4

5. CU Radio

1

1

6. $96.5 \mathrm{FM} \mathrm{Mсот}$

8

9

7. Thai PBs Radio

26

26

8. FM 99 Active Radio

16

17

9. FM 100.5 мсот News

$3^{1}$

31

5

Network

10. Nation Radio

34

34

11. 88 FM NBT Radio Thailand

5

5

Bangkok

Frequencies of

133

$133 \quad 0$

3

141

language use 
TABLE 3.10 Vietnam

No. Name of station

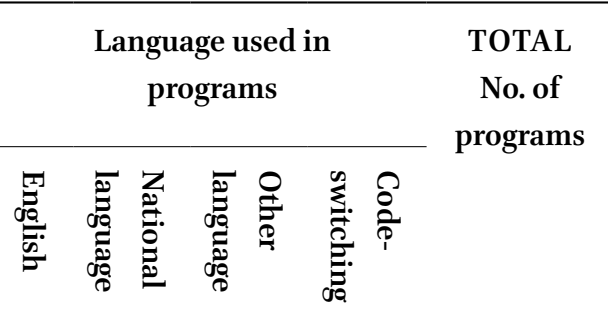

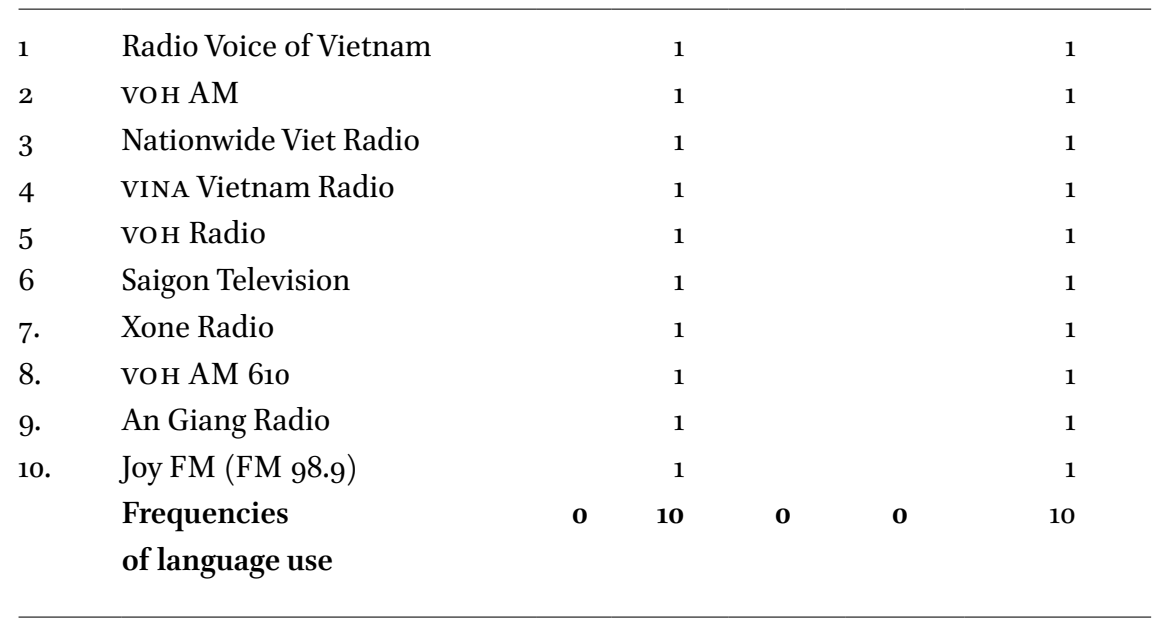

